\title{
Digital Micrometer Used in Thickness Measurement of Plastic Film Compared to Standardized Instrument
}

\author{
Carlos Eugênio Fortes Teixeira ${ }^{1}$, Ingrid de Almeida Rebechi ${ }^{2}$, Renato Serena Fontaneli ${ }^{3}$ \\ ${ }^{1}$ Técnico em Mecânica/Engenharia Mecânica-IFSul—campus Passo Fundo, Passo Fundo, Brazil \\ ${ }^{2}$ Agronomia-IDEAU. Bolsista PIBIC/CNPq, Passo Fundo, Brazil \\ ${ }^{3}$ Agronomia/ppgAgro UPF-Universidade de Passo Fundo/pesquisador EMBRAPA TRIGO, Passo Fundo, Brazil \\ Email: carlos.teixeira@passofundo.ifsul.edu.br
}

How to cite this paper: Teixeira, C.E.F., de Almeida Rebechi, I. and Fontaneli, R.S. (2017) Digital Micrometer Used in Thickness Measurement of Plastic Film Compared to Standardized Instrument. Materials Sciences and Applications, 8, 577-583. https://doi.org/10.4236/msa.2017.87040

Received: May 7, 2017

Accepted: July 16, 2017

Published: July 19, 2017

Copyright ( 2017 by authors and Scientific Research Publishing Inc. This work is licensed under the Creative Commons Attribution International License (CC BY 4.0).

http://creativecommons.org/licenses/by/4.0/ (c) (i) Open Access

\begin{abstract}
Different types of plastic films are used in agriculture to cover silos storing silage. The most important characteristics of a tarpaulin for sealing the silage are: thickness, color and polymer used in the manufacture of the film. The objective of this study is to measure and compare the thickness, the use of two instruments (digital micrometer and digital thickness gauge) in plastic films (polyethylene, polyester and polyester/vinyl). This methodological analysis for the use of micrometer digital, for future use (Agronomy and Veterinary sciences). In comparison the thickness of the three factors. $5 \%$ by Tukey test revealed that for polyethylene, there was no significant difference between factors. This methodology is satisfactory for the types of films and range of thicknesses studied.
\end{abstract}

\section{Keywords}

Methodology, Standardization, Polymers

\section{Introduction}

Polyethylene film (PE) is commonly used for various purposes, one of which is the coverage silos and silage. Polyethylenes, are thermoplastics from the group of polyolefins, are very important material and are present in large numbers and in different ways, in everyday society [1]. Polyesters, as the name implies, are polymers having the ester function. The fibers of polyesters can be molded by extrusion or lamination processes with other polymers such as vinyl polymers nature and give rise to different types of films [2] [3]. The cover canvas represents an important contribution, in the silo sealing stage, with the objective of reducing 
the penetration of air from the external environment to the interior. The most important characteristics of a tarpaulin for silage sealing are: Thickness, coloring and polymer used in the making of the film [4] [5]. In surface silos, the canvas becomes indispensable for protection, and there is demand for thicker films (180 to $200 \mu \mathrm{m}$ ) [5]. The function of a plastic when used for silo sealing is to create an anabolic condition and thus provide a good environment for fermentation. There are studies that have demonstrated the effects of the concentration of $\mathrm{O}_{2}$ inside the silo, causing losses of dry matter, nutrients, accumulation of pathogens [4] [5] [6] [7].

The types of plastic films in our country, used in silos as hedges are polyethylene main polymer, different colors and different thicknesses ranging from 150 to $300(\mu \mathrm{m})[6]$. The black canvas and "thick" commercial $150 \mu \mathrm{m}$, showed a value of $81 \mu \mathrm{m}$ below, which was published by the manufacturer [8]. In blowing ratio of study (RS) for tubular films of LDPE (low density polyethylene) and HDPE (high density polyethylene), it was found that the results of the thicknesses of the films in different compositions (specifications) were not concerned, for the distribution of defined thickness (average $60 \mu \mathrm{m}$ ) [9]. The thickness of the films is a parameter that may interact and relate to different properties (ex: gas permeability) [6]. When it comes to frequently manufacture plastic films with thickness according to specifications, customers have greater satisfaction, contributing to the success of the enterprise and better market position in relation to competing organizations [10].

In order to evaluate the thickness of the films, it is important to evaluate the uniformity of these materials, the repeatability of the measurement, their properties and make comparisons between films [10]. The plastic films of polyethylene used to cover silages have permeability to oxygen; and this tends to increase as it rises to room temperature [3] [6] [11]. In silage study applications, for agronomic and veterinary sciences, the fermentation parameters that are related to the thickness of the silo cover are quite variable; Polyethylene films are the most used for silage coverage today. The films of polyester or polyester/vinyl, are films with greater thickness; Its use was abandoned due to the high cost of acquisition per square meter, although the latter have better mechanical and barrier properties than polyethylenes [7]. The studies carried out in the area of silage, related commercial thicknesses reported by the manufacturers. They do not consider the relation of the actual variation of the thickness as a function of the temperature. It is possible to use a methodology to use the digital micro-meter in these works. Without the need for sophisticated equipment and laboratory environment. The novelty of this study lies in the fact that it will also serve to determine new gas permeability coefficients in silage studies, which should in future consider these environmental variations and thickness. Since the processes of obtaining a uniform thickness by the manufacturers of plastic films, are still in evolution, the evaluation of the thickness "in situ" will be extremely important to evaluate the time and quality of the silage produced. Therefore, the objective of this study is to measure and compare the thickness, the use of two instruments (digital micrometer and digital thickness gauge) in plastic films (polyethylene, 
polyester and polyester/vinyl), for future use.

\section{Material and Methods}

The materials used to study the thickness of the plastic films were three types of commercial plastics films and two types of instrument for measuring thickness. Mercury thermometer graduated from $-20^{\circ} \mathrm{C}$ to $120^{\circ} \mathrm{C}$. Low density polyethylene film (LDPE) of $130 \mu \mathrm{m}$. Polyester Film Polyester $300 \mu \mathrm{m}$ and $370 \mu \mathrm{m}$ vinyl film, all the nominal thickness (depending on the manufacturer). Digital micrometer $0-25 \mathrm{~mm}-0.001 \mathrm{~mm}$. Digital thickness gauge-0 - $10 \mathrm{~mm}-0.001 \mathrm{~mm}$. Action 2.8 software. The methodology for verification of the thickness consisted primarily of cut 15 samples $-100 \mathrm{~mm} \times 100 \mathrm{~mm}$ size (determining the sample surface $=10,000 \mathrm{~mm}^{2}=100 \mathrm{~cm}^{2}$ ) each of the films (polyethylene, polyester and polyester/vinyl). Under each sample were made ten (10 measurements) thickness using the digital micrometer. Every 5 readings performed to "reset" for 5 readings and so forth. For the readings do not coincide on the same point read, ran up an anti-clockwise movement on the surface of the sample, from the center towards the periphery, simulating a "snail" or helical. Later on other film samples with the same characteristics of the above (15 new samples of films), took up 10 measurements using the milesimal thickness meter. These values were tabulated in the order, as it was in the measurements. The relative humidity in the atmosphere was $61 \%-65 \%$, extracted data tab, for table psychometric relations (Tbs-Tbu), where Tbs is the dry bulb temperature; Tbu is the wet bulb temperature. The time between each measurement was about 2 minutes. For in each sample was made 10 determinations, requiring careful not to measure on the same point and leave a relaxation time to make up the next measurement. The results of the readings (two plus the thickness gauges provided manufacturers) amounted to three factors (thickness of manufacturer, thickness-micrometer and thickness-normalized. Subsequently, application of the Tukey test at $5 \%$ significance and linear regression, for use of Action 2.8 software.

\section{Results and Discussion}

The results for Polyethylene film, measured with micrometer is $119.46 \mu \mathrm{m}$ (Table 1). In polyester films values were minimum observed variation is $8 \mu \mathrm{m}$. Already in polyester films with vinyl layer these values greater variation observed is 17 $\mu \mathrm{m}$. In comparison the thickness of the three factors (manufacturer, using standard micrometer-use of the thickness gauge), $5 \%$ by Tukey test revealed that for polyethylene, there was no significant difference between factors. For Ferreira (2012), thin films of LDPE, when stretched deform evenly. According to the same author, the handling of these materials before and during the crystallization step, influences the solid state properties [9]. For the polyester film (Table 2), we observed a significant difference only between the thickness of the manufacturer and read the micrometer. In comparison to polyester film/vinyl (Table 3), the thickness read in standard apparatus was superior in $10.26 \mu \mathrm{m}$ the commercial value reported by the manufacturer. Being $9 \mu \mathrm{m}$, the value of the top 
Table 1. Group measures for polyethylene $130 \mu \mathrm{m}$.

\begin{tabular}{ccc}
\hline Measures for polyethylene & Mean & Groups \\
\hline Thickness Manufacturer $(\mu \mathrm{m})$ & 130 & $\mathrm{a}$ \\
Normalized thickness $(\mu \mathrm{m})$ & 125.46 & $\mathrm{~b}$ \\
Micrometer thickness $(\mu \mathrm{m})$ & 119.46 & $\mathrm{c}$ \\
Average & 124.97 & \\
$\mathrm{CV}(\%)$ & 2.68 & \\
\hline
\end{tabular}

Table 2. Group measures to polyester $300 \mu \mathrm{m}$.

\begin{tabular}{ccc}
\hline Measures for polyester & Mean & Groups \\
\hline Thickness Manufacturer $(\mu \mathrm{m})$ & 300 & $\mathrm{a}$ \\
Normalized thickness $(\mu \mathrm{m})$ & 297.73 & $\mathrm{ab}$ \\
Micrometer thickness $(\mu \mathrm{m})$ & 295.33 & $\mathrm{~b}$ \\
Average & 297.68 & \\
CV $(\%)$ & 2.60 & \\
\hline
\end{tabular}

Table 3. Group measures to polyester/vinyl $370 \mu \mathrm{m}$.

\begin{tabular}{ccc}
\hline Measures for polyester/vinyl & Mean & Groups \\
\hline Normalized thickness $(\mu \mathrm{m})$ & 380.26 & $\mathrm{a}$ \\
Thickness Manufacturer $(\mu \mathrm{m})$ & 370 & $\mathrm{~b}$ \\
Micrometer thickness $(\mu \mathrm{m})$ & 361 & $\mathrm{c}$ \\
Average & 370.42 & \\
$\mathrm{CV}(\%)$ & 4.81 & \\
\hline
\end{tabular}

manufacturer taken by micrometer; the maximum difference was between the value read on the standard instrument and micrometer $(19.26 \mu \mathrm{m})$. These results are the study of the meeting made by Alencar (2011): Some companies, it can be inferred that the main causes for the problem, with the thickness, result from malfunctions of extruders, the wear parts, the process weighing of raw materials to be inadequate and the lack of precision of the measurements taken by the instrument used in process control (the micrometer) [10]. In study of the orientation processes are commonly employed to modify the film properties: as optical, mechanical, and barrier to gases, in addition to altering the thickness and the flexibility thereof. It brings out that the two instruments used, have the resolution $(0.001 \mathrm{~mm}$ or $1 \mu \mathrm{m})$ suitable for the task (measuring plastic films) [8]. For bioplastics, based on lipophilic starch and glycerin obtained by thermoplastic extrusion process, Carvalho et al. (2010) adapted and created a technique for determining the thickness of bioplastics with the use of a micrometer (Model MDC-25M, Mitutoyo ${ }^{\circ}$, Japan), the average of 10 random measurements in different parts of the film. Measures taken after conditioning the film for 48 hours at $25^{\circ} \mathrm{C}$ and $50 \% \mathrm{RH}$ [5]. For tubular films every RS adjustment (ratio of breath) 
occur thickness variation on the perimeter of the film. The explanation resides in the influence of the matrix design and air cooling ring, the rheological characteristics of the polymer and processing conditions, influencing the flow behavior of the molten material by the die and subsequent attachment of the film geometry [9]. The largest fluctuation and higher normalized values in polyester films and polyester/vinyl, lies the irregular arrangement of the fibers in the matrix material and non-uniform deposition of the vinyl layer over it; in the process of lamination of films; Apart from handling in manufacturing and marketing, in whole or in part of fibers of these materials. By using digital thickness gauge, a significant difference was observed occur for nominal thickness value reported by the manufacturer in the polyethylene film and polyester/vinyl (Table 1 and Table 3). The obtained regression models for use micrometer; through collected data and use the software, configure the following equations:

$$
\begin{gathered}
\text { Polyethilene: } y=166.71-1.97 x ; R^{2}=0.36 \\
\text { Polyester: } y=328.19-1.482 x ; R^{2}=0.27 \\
\text { Polyester-vinil: } y=462.175-4.275 x ; R^{2}=0.66
\end{gathered}
$$

Correlations have been shown for the weak polyethylene and polyester, by virtue of a greater thickness variation for the same temperature (Figure 1 and Figure 2); this can be explained due to a smaller variation in thickness, when observing the same temperature measurement (Figure 2). The linear regression models, created by the software, evidence the decrease of the thickness for all the plastic films tested, as it happens, the increase in the ambient temperature (Figures 1-3).

It can be explained, in the effect of altering the dimensional stability, by the surface stretching of the polymer molecules; Caused by the alteration between amorphous and crystalline zones or in the fibers [2] [3] [6] [12], promoted by contact with the micrometer measuring surfaces (Measuring Pressure).

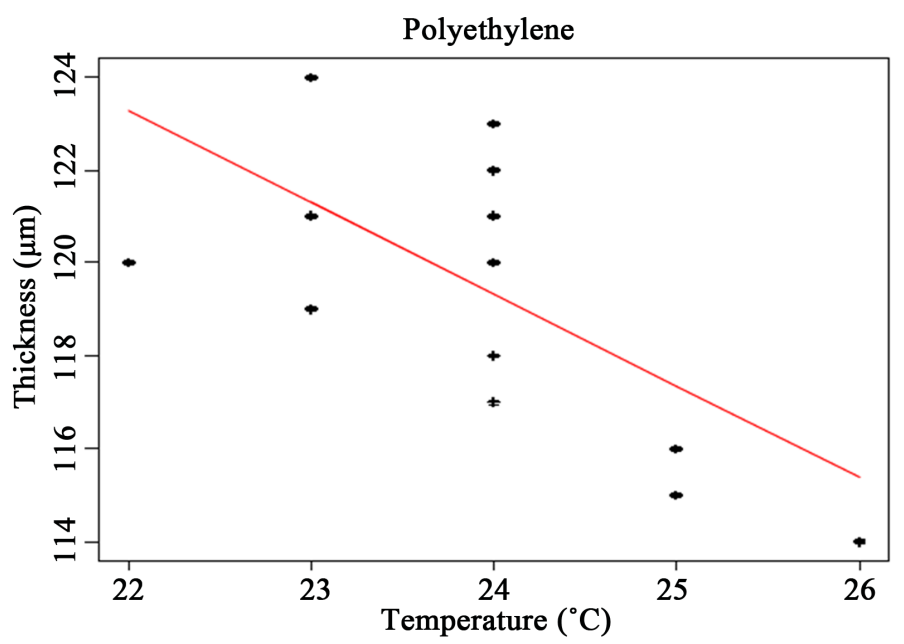

Figure 1. Set Model graph for Polyethylene-thickness taken in micrometer $(\mu \mathrm{m}) \times$ temperature $\left({ }^{\circ} \mathrm{C}\right)$. 


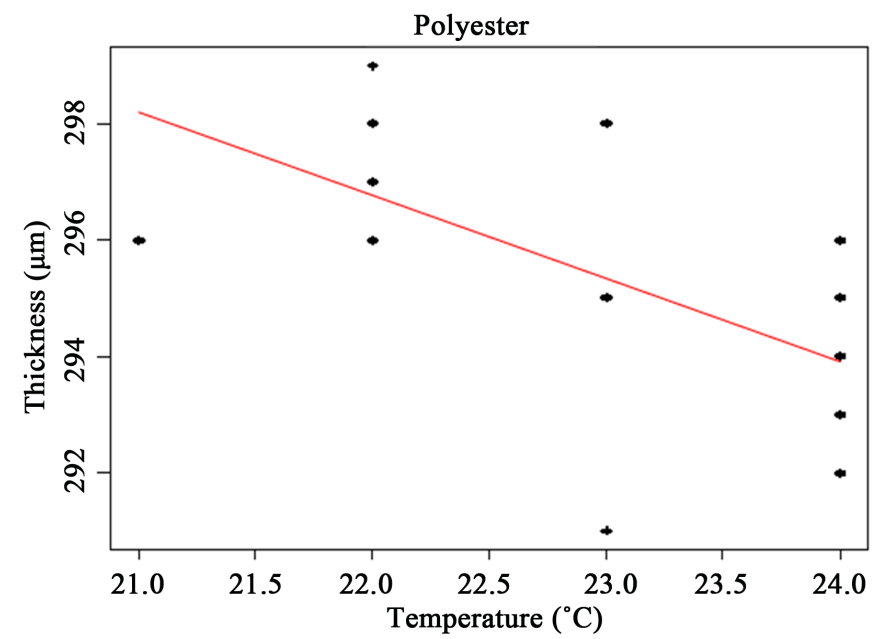

Figure 2. Set model graph for polyester-thickness taken in micrometer $(\mu \mathrm{m}) \times$ temperature $\left({ }^{\circ} \mathrm{C}\right)$.

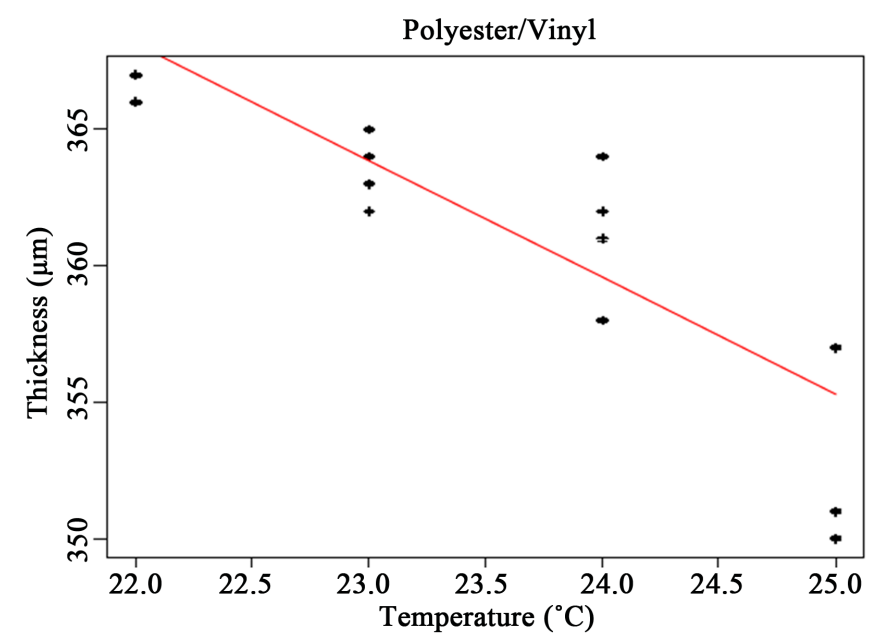

Figure 3. Set Model graph for polyester/vinyl-thickness taken in micrometer $(\mu \mathrm{m}) \times$ temperature $\left({ }^{\circ} \mathrm{C}\right)$.

The difference in the models presented between films can also be attributed to the different coefficients of thermal expansion: represented by the different nature of these materials and the manufacturing processes by which they have passed [2] [3]. The correlation between thickness and temperature was stronger in the polyester/vinyl film $\left(R^{2}=0.66\right)$ (in equation), evidenced by the previously reported effects. The coefficient of variation is indicated in the tables by $\mathrm{CV}$ (Tables 1-3). The graphics adjusted model are below. The results discussed above correspond to data from 2014 and 2015.

\section{Conclusion}

Considering that standardized tools to measure the thickness of films are costly, the use of a digital micrometer for the reading of plastic films becomes useful in this type of use: this methodology for use in Agronomy science and Veterinary science is satisfactory for the types of films and range of thicknesses studied. 


\section{References}

[1] da Silva Oliveira, E.I., Silveira, F., Viveiros, A.M.V., Basso, N.R.S., da Rocha, Z.N. and dos Santos, J.H.Z. (2015) A versatilidade dos compostos de coordenação na produção de polietilenos: uma revisão dos sistemas catalíticos. Química Nova, 38, 97-105.

[2] Mano, E. and Mendes, F. (2010) Introdução a Polímeros. 4th Edition, Ed. Bluncher, São Paulo, 191 p.

[3] Michaeli, W., Greif, H., Kaufmann, H. and Vosseburger, F. (2008) Tecnologia dos Plásticos. 3rd Edition, Ed. Bluncher, São Paulo, 205 p.

[4] Bernardes, T.F., Amaral, R.C.. Reis, R.A., Siqueira, G.R., Roth, A.P.T.P., Roth, M.T.P. and Berchielli, T.T. (2008) Perfil fermentativo, estabilidade aeróbia e valor nutritivo de silagens de capim-marandu ensilado com aditivos. Revista Brasileira de Zootecnia/Brazilian Journal of Animal Science, 37, 1728-1736. https://doi.org/10.1590/S1516-35982008001000003

[5] de Carvalho, C.W.P., Fakhouri, F.M., Ascheri, J.L.R., Takeiti, C.Y., Bilck, A.P, Yamashita, F. And Mei, L.H.I. (2010) Bioplásticos à base de amido lipofílico e glicerina obtida por processo de extrusão termoplástica. PlastShow 2010, São Paulo-SP, 10 p.

[6] Bernardes, T.F. and do AmaraL, R.C. (2011) Lona para a vedação da silagem: Estamos sendo enganados?

http://www.milkpoint.com.br/radar-tecnico/conservacao-de-forragens/lona-para-avedacao-da-silagem-estamos-sendo-enganados-49719n.aspx

[7] Benning, C.J. (1983) PLASTIC Films for Packaging, Technology, Applications and Process Economics. Technomic Publishing Company, Inc., Lancaster, PA.

[8] Ferreira, R.L.R. (2012) Estudo da influência da razão de sopro na estrutura e propriedades de filmes de polietilenos produzidos pelo processo de extrusão tubular. [dissertação] Programa de pós graduação em engenharia de minas, metalurgia e de materiais. UFRGS-Universidade Federal do Rio grande do Sul, Porto Alegre-RS, $125 \mathrm{p}$.

[9] de M. Alencar, E.D., Feijo, J.L., da Rocha, C.I.L., Rosa, F.A.C.S. and dos Santos Jr., E.C. (2011) Método de análise e solução de problemas (MASP) e ciclo PDCA: uma abordagem voltada à redução de variabilidade no processo de produção de filmes plásticos. XXXI ENCONTRO NACIONAL DE ENGENHARIA DE PRODUCAO. Belo Horizonte, $M G, 11 \mathrm{p}$.

[10] Cuq, B., Gontard, N., Cuq, J.L. and Guilbert, S. (1996) Functional Properties of Myofibrilar Protein-Based Biopackaging as Effected by Film Thickness. Journal of Food Science, Chicago, 61, 580-584. https://doi.org/10.1111/j.1365-2621.1996.tb13163.x

[11] Ferreira, R.L.R. and Santana, R.M.C. (2015) Estudo comparativo da influência da razão de sopro nas propriedades de filmes tubulares de PEBD e PEAD. Polímeros: Ciência e Tecnologia, 25, 83-93. https://doi.org/10.1590/0104-1428.1618

[12] Savoie, P. and Jofriet, J.C. (2003) Silage Storage. In: Buxton D.R., Muck R.E. and Harrison, J.H., Eds., Silage Science and Technology, American Society of Agronomy, Madison, Vol. 1, 405-468.

https://dl.sciencesocieties.org/publications/books/pdfs/agronomymonogra/silagesci encean/405 
Submit or recommend next manuscript to SCIRP and we will provide best service for you:

Accepting pre-submission inquiries through Email, Facebook, LinkedIn, Twitter, etc. A wide selection of journals (inclusive of 9 subjects, more than 200 journals)

Providing 24-hour high-quality service

User-friendly online submission system

Fair and swift peer-review system

Efficient typesetting and proofreading procedure

Display of the result of downloads and visits, as well as the number of cited articles Maximum dissemination of your research work

Submit your manuscript at: http://papersubmission.scirp.org/

Or contact msa@scirp.org 